\title{
Planning Evaluation in Career Development of Lecturers from Indonesian Armed Forces at Indonesia Defense University
}

\author{
Tatar Bonar Silitonga ${ }^{1 *}$, Zahara Tussoleha Rony ${ }^{2}$ \\ ${ }^{1}$ Manajemen Pertahanan, Universitas Pertahanan \\ ${ }^{2}$ Universitas Bhayangkara Jakarta Raya
}

\begin{abstract}
This study was conducted to evaluate planning in career development for lecturers with the status of TNI (Indonesian Armed Forces) soldiers at Indonesia Defense University (IDU). The evaluation adopted the Countenance Stake model which conceptualizes a description matrix containing intents and observations and a judgment matrix containing standards and judgments. The evaluation focused on regulatory bases, program supports, as well as monitoring and evaluation planned to support lecturers' careers. The qualitative design used in this study is supported by primary and secondary data obtained through literature studies, observations, and interviews. Data analysis was conducted through the interactive approach of Miles and Huberman in data display activities, data reduction, and drawing conclusions. The results of the study show that planning in career development for lecturers from Indonesian Armed Forces (TNI) has been sufficiently supported by good results (84\%), through basic support for external and internal policies, Tridharma Perguruan Tinggi (Three Pillars of Higher Education comprising Education, Research and Community Service) program and supporting elements, as well as plans for monitoring and evaluating performance.
\end{abstract}

Keywords

Planning, Career development, Lecturers, Soldiers

Article Received: 20 September 2020, Revised: 30 November 2020, Accepted: 18 December 2020

\section{Introduction}

The importance of the lecturer's role is beyond doubt. Lecturers play a role in producing quality graduates (Harison \& Faisal, 2017), improving human quality and educating the nation's life (Auliana \& Nurasiah, 2017), and as a workforce (Arokiansamy et al., 2009). The affirmation of the role of lecturers is mandated in Law Number 14 of 2005 concerning Teachers and Lecturers, Government Regulation Number 37 of 2009 concerning Lecturers, and various related laws and regulations. According to these regulations, lecturers are defined as professional educators and scholars with the main task of transforming, developing, and disseminating science, technology, and arts through education, research, and community service.

The importance of the lecturer's role requires lecturers' professional development that can be performed systematically. The linear role of lecturers and career development will encourage lecturers to perform well. Lecturers' career development is closely related to the role of the organization where the lecturer is assigned. Proper management and empowerment of resources will contribute to organizational performance (Damanik \& Bangun, 2018; Sukoco \& Prameswari, 2017). Career development is related to the process executed by an organization in order to change the status, position, or function of someone working in the organization (Muspawi, 2017).

Career development contains a comprehensive meaning, which includes planning to the end of a lecturer's career or service. By applying development system appropriately, according to experience, such a context, will encourage the effectiveness of lecturers' development. Thus, lecturers will carry out their job responsibilities properly and reciprocally, the lecturers will perform in their careers earnestly in accordance with the task load they are carrying.

Career development process of lecturers at Indonesia Defense University (IDU) is interesting to be explored with the number of lecturers from TNI (Indonesian Armed Forces) soldiers in a total 
of $54 \%$ of the total 193 permanent lecturers in the master program. Factually, TNI soldiers have a standard model of training in their careers. Within the TNI, there are also career lecturers such as in the Force Academy. However, based on comparisons, the model of lecturer development at Indonesia Defense University has implemented a cum-based assessment system or performance achievement that applies to functional positions and besides that, based on the career regulations for lecturers at IDU, it is possible to reach the highest level of position and rank which is equivalent to a lecturer with an employee status state or other under the guidance of the Ministry that regulates education.

It is not surprising that there are indications that a career in a functional position is the second choice among the TNI. Structural positions are usually more attractive (Silitonga, 2008). On the other hand, there are several trends that soldiers who start their careers at IDU are personnel approaching retirement from serving the TNI. With these various backgrounds, it is deemed necessary to evaluate the career development of lecturers with the status of TNI Soldiers at IDU, with restrictions on the planning.

Planning is one of management functions. Planning is the first function of management which mandates the preparation of everything by taking into account organizational resources and anticipating potential obstacles to achieving certain goals. Terry (2016) emphasizes the importance of planning and is the intellectual arm of future development. Robbins and Coulter (2010) state that planning is related to the end result (what) and the means (how). Basuki Wibawa (2017) explains that planning is an activity to think about the future and the future without planning is nonsense. The importance of planning to support the success of an activity is not in doubt. There is even a saying when failing at planning that means we plan to fail. Undeniably, no one wants to plan for failure. The problem is whether the planning has been executed properly.

Planning as part of the management functions in today's era is not only understood as a concept, but is also applied in various dimensions including programs and activities, applied in both private and public organizational sectors. Obviously, the planning that is meant here is formal planning. Formal planning is carried out with certain criteria so that if these criteria are met and then implemented properly, it will support the achievement of maximum results. Meeting the criteria confirms that a plan is not an end product and stops when the formulation has been carried out. In accordance with the problems in this study, there is a sense of urgency in analyzing the planning of career development for lecturers, especially lecturers with the status of TNI soldiers at IDU. The analysis was conducted by analyzing data to conclude the career development process, especially in the aspect of lecturer planning.

The demand for precision in a planning program is a fundamental element for the effectiveness of a plan. Precision criteria do not mean planning without the possibility of making adjustments. Contextually, it is acknowledged that there are dynamics or uncertainties that occur around program implementation, including constraints and challenges according to program areas. The planning that is prepared is expected to be able to anticipate the obstacles and challenges faced. Planning should be formulated flexibly so that it is possible to be revised or developed as needed. Policies and programs prepared are expected to be able to function to ensure the flexibility of planning in order to support its precision in achieving maximum results.

\section{Literature Review}

Evaluation of lecturers' career development planning is seen as an activity to gather information about planning readiness in supporting lecturer career development. Career development is basically a series of activities performed starting from planning to end of service. Career can be defined as a number of work positions held by a person during the work life cycle from the lowest position to the top position (Sinambela in Muspawi, 2017). Career development can be defined as a personal improvement made by a person to achieve a career plan and an increase by the personnel 
department to achieve a work plan with an organizational path or level (Ardana, 2012: 117). Career development in an individual perspective is an effort by personnel to make career advancement, while a career in an organizational perspective is an effort made by an organization to develop an employee's career. Career development carried out by the organization can foster employees' commitment (Dessler, 2009: 6). A good career development must be integrated into the company / organization plan (Rony, 2016).

Career development planning in the context of higher education management as implemented by IDU is included as part of the quality education system. The implementation of quality education is an activity to prepare and anticipate appropriately so that its implementation can run smoothly and achieve the goals as expected. Basuki Wibawa (2017) mentions some important points as a guide in preparing a plan including things related to the future, a set of activities, a systematic process, and certain results/goals. In addition, planning functions include guidelines for implementation and control, avoiding waste of resources, tools for developing quality assurance, and efforts to fulfill institutional accountability. From this context, it can be seen the importance of planning for the effectiveness of implementing a program. In this case, its effectiveness starts with career development planning which will be explored based on a basic review of regulations, program supports, and monitoring and evaluation plans.

Regulation is a policy provision that is used as a guide in career design. Careers need to be designed so that there is a clear direction and purpose. Policy can be interpreted as a guide for action. According to Sabdaningtyas (2018), a policy can be in the form of a declaration on the

\section{Method}

This study used a qualitative design with an evaluation approach. Creswell (2017) mentioned qualitative as a method for exploring and understanding the meaning that a group of people believe comes from a social or human problem. basis of guidelines for a specific direction of action, a program regarding certain activities or a plan. Therefore, policies are provisions that must be used as references, guidelines, tools, directions, and methods for every business and activity so that continuity and integration can be achieved in attaining certain goals.

A program is a form of activity or activity that is planned to support certain goals. The programs referred to in this discussion are various activities held in the education program at IDU which are related to lecturers' career. The program referred to can be more of an activity performed for certain targets but is included in the context of a career development program because it is still correlated. The learning program, for example, is an activity aimed at realizing learning outcomes, in this context the lecturers become the teacher and the implementation of learning contains credit scores for lecturers' career assessment.

Monitoring and evaluation is a control plan for various activities so that the process can run according to plan. This clearly shows the importance of monitoring and evaluation so that something that has been outlined and programmed can perform as it should. Planning precision in the development of lecturers' careers at IDU is closely related to the demands for accountability in the administration of higher education. The law on education that was enacted by the Indonesian government mandated the implementation of quality-based education. IDU as a university implements education quality management through internal and external quality assurance systems. In that context, career development planning is included. There is a demand to go through the management stage which, among others, is to see the level of accountability shown by the monitoring and evaluation process.

Evaluation and planning are social problems. These social characteristics can be clearly seen from the subjects of this study, namely lecturers, university management, faculty management, and study program management at the IDU environment who are believed to know the problems being studied. Regarding the evaluation approach, The Joint Committee as cited by 
Stufflebeam and Coryn (2014) defined evaluation as the systematic assessment of the worth or merit of an object. According to Arikunto and Jabar (2014), evaluation is an activity to gather information to determine the right alternatives in making decisions..

The evaluation used adopted the Countenace Stake model. This model conceptualizes three components of the object under study including antecedent, transaction, and outcomes. This study took only one part of the model concept, namely the antecedent component with a focus on components including regulatory bases, program supports, and monitoring and evaluation plans. This component is more detailed on various aspects and the assessment was seen based on its correlation in supporting the lecturers' career. The aspect of community service and supporting elements, for example, is considered to have a smaller percentage compared to aspects of teaching and research education. According to Silitonga (2020), in the process, the concept of this model presented a description matrix (presentation of intents and conducting observations) and judgment matrix (checking against standards and equipped with considerations). From this process, recommendations that are deemed necessary to be adjusted with the results of the evaluation were given.
Data was collected through literature studies, interviews, and observations (Rony, 2017; Silitonga, 2020). Data collection was for planning of career development for TNI-soldier lecturers and their suitability with evaluation of regulatory bases, program supports, and monitoring and evaluation plans. To interpret the data, a qualitative descriptive analysis was used. The data was then analyzed using Miles \& Huberman (1992) steps, through data display, data reduction, and retrieval.

Achievement level of the results from each planning component and its respective aspects was evaluated and assessed from 0 to 100 . The score for each element was adjusted to the fulfillment of the criteria. The data that has been reduced and presented are then compared with the evaluation criteria that have been set and the expected goals with interpretations adapted from the type of scoring developed by Arikunto in Lukum (2015), starting from the very good, good, satisfactory, and poor. The scoring was used as a category of interpretation of the level of availability and achievement of each component as well as the evaluated aspects as shown in the table below:

Table 1. Category of Data Interpretation from Research Results

\begin{tabular}{cccc}
\hline No & Percentage Scale & $\begin{array}{c}\text { Grade } \\
\text { Category }\end{array}$ & $\begin{array}{c}\text { Predicate } \\
\text { Evaluation of } \\
\text { Result }\end{array}$ \\
\hline 1 & $85 \leq \mathrm{NA} \leq 100$ & $\mathrm{~A}$ & Excellent \\
\hline 2 & $70 \leq \mathrm{NA} \leq 85$ & $\mathrm{~B}$ & Good \\
\hline 3 & $56 \leq \mathrm{NA}<70$ & $\mathrm{C}$ & Fair \\
\hline 4 & NA $<56$ & $\mathrm{D}$ & Poor \\
\hline
\end{tabular}

Source: Arikunto in Lukum (2015)

\section{Result and Discussion}

Planning for career development of TNI-soldier lecturers at IDU according to research result is described in a summary of data from various data collection sources, analysis of conformity with evaluation criteria, assessments and decisions as research findings on regulatory bases, program supports, and monitoring and evaluation as described below:

\section{Regulatory Bases}

Regulations or policies in the form of written documents were the bases for career development 
of lecturers. Regulations are urgently needed to be referred by various stakeholders including civil servants, IDU management both study program and top management, as well as lecturers. On the basis of regulations, stakeholders can avoid possible mistakes in the lecturers' career development process. The lecturers will use written documents as a basis to plan and develop a career.

Based on the data, there were various findings about regulations or policies that served as guidelines for lecturers' career development. In general, the regulations referred to include various regulations related to lecturers issued by institutions outside IDU as well as those directly issued by IDU in a form of a Rector Regulation. Regulations originating from institutions outside IDU were also part of IDU Guidelines that must be utilized by the fact that IDU TNI-soldier lecturers' career development cannot be separated from various other institutions. Proposals for lecturer promotion and ranking must go through the process of calculating the lecturers' credit score, which bases from calculation refers to the provisions stipulated by authorized government officials.

Regulations related to the career of lecturers from outside IDU include Law No.14/2005 on Teachers and Lecturers, Government Regulation No. 37 concerning Lecturers, Presidential Regulation No. 64/2014 on Indonesia Defense University Lecturers, Regulation of Ministry of Administrative and Bureaucratic Reform on Functional Position, and the Minister of Defense Regulation on Defense Lecturers, Regulation of Ministry of Defense on OTK, Regulation of Ministry of Defense on the List of Personnel Composition. Regulation of the Ministry of Education and Culture on Organization and Work Procedures, Regulation of the Minister of Education and Culture regarding Indonesia Defense University Statute, Regulation of the TNI Commander regarding Soldiers Serving Outside the TNI Organization. Regulation of Ministry of Research Technology and Higher Education No. 62/2016 on the Quality Assurance System for Higher Education and has been referred to by IDU through the stipulation of a Rector Regulation on Internal Quality Assurance System Policy.

The issuance of Presidential Regulation No. 64/2014 on Indonesia Defense University Lecturers, among others, mandates the existence of TNI Soldiers at the officer level with minimum academic qualifications of master to become lecturers. Previously, TNI soldiers could have a career as a lecturer and an assignment as a lecturer in the internal education environment of the TNI and the Ministry of Defense such as TNI military's Staff and Command School, Armed Forces Staff and Command School in the Force Academy, and other educational institutions. Heretofore, the assignment to become a lecturer prior to the issuance of Presidential Decree No. 64/2014, in the implementation of lecturer career development for soldiers has not been based on the pattern of fostering a lecturer credit score as applicable to lecturers as mandated in the law on lecturers.

Based on the external policy data, there are policies that are directly related to IDU, such as the Presidential Decree and Regulation of the Minister of Defense regarding Indonesia Defense University Lecturers. Referring to the results of data collection, the regulation was initiated by Indonesia Defense University. IDU took steps according to the procedure so that there is clarity in lecturers career development. Higher officials then initiated the authority according to formal channels, including involving the role of the Ministry of Defense as an Indonesia Defense University guidance institution.

Various regulations were referred to and used as bases according to the interests, referring to points that are directly related to lecturers' career development at IDU. The Law on Teachers and Lecturers as well as Government Regulations on lecturers, for example, were the bases of basic explanation of the profession of lecturers as professional educators. Furthermore, the statement which specifically mentioned TNI Soldiers as part of the lecturers at IDU is stated in the Presidential Regulation on Defense Lecturers and the Ministry of Defense Regulation on IDU Lecturers, a policy initiated by IDU. 
Based on the Presidential Decree and Ministry of Defense Regulation on IDU Lecturers, it is clearly stated that the career of TNI-soldier lecturers is based on the provisions regarding functional positions starting from the position of assistant expert, lector, chief lecturer, to professor, with the provision of fulfillment of credit points (cum) in line with the provisions of the credit score as stipulated in the regulations on lecturers. TNI soldiers working as lecturers at IDU were determined from the rank of first lieutenant to the rank of three stars according to their credit score achievements.

Referring to the results of data collection, provisions for positions and ranks stipulated in the Presidential Decree and Regulation of MInistry of Defense on IDU lecturers were not equipped with implementation provisions that accommodate these policies within the TNI. Given the fact that Presidential Decree is a policy issued by the President as the Supreme Commander of the TNI, the derivative of the Presidential Decree is very logical and important to be carried out. Therefore, complete regulations from the TNI Commander are still needed to accommodate the position of IDU lecturers and proposals for promotion for lecturers from the TNI.

The regulations related to lecturers issued by IDU with the Rector stipulation include the Defense University Rector Regulation on Lecturer Guidance, Rector Regulation on Lecturer Recruitment, Rector Regulation on Lecturer Workload, Rector Regulation No. 12/2015 on Standards for IDU Lecturers and Education Personnel, Rector Regulation No. 57/2015 on Giving of Awards and Sanctions at IDU, Rector Regulation Number 72/2015 on Guidelines for Lecturer Performance Assessment at Indonesia Defense University.

Data related to regulatory bases are summarized and presented in the following table:

Table2. Basic Evaluation of Lecturer Career Regulations

\begin{tabular}{|c|c|c|c|}
\hline \multicolumn{2}{|c|}{ Description Matrix } & \multicolumn{2}{|c|}{ Judgement Matrix } \\
\hline Intens & Observation & Standard & Judgement \\
\hline $\begin{array}{l}\text { 1) Complete } \\
\text { external } \\
\text { regulatory } \\
\text { bases }\end{array}$ & $\begin{array}{l}\text { There were } \\
\text { regulatory bases in } \\
\text { the form of Laws, } \\
\text { Government } \\
\text { Regulations, } \\
\text { Presidential Decree, } \\
\text { and Regulation of } \\
\text { Ministry of Defense } \\
\text { which were } \\
\text { operational in } \\
\text { relation to IDU } \\
\text { lecturers, but were } \\
\text { not supported by } \\
\text { TNI Commander's } \\
\text { Regulation which } \\
\text { specifically related } \\
\text { to IDU lecturers. }\end{array}$ & $\begin{array}{l}\text { There are regulatory } \\
\text { bases in the forms of } \\
\text { Laws, Government } \\
\text { Regulations, } \\
\text { Presidential Decrees, } \\
\text { Regulation of } \\
\text { Ministry of Defense, } \\
\text { and TNI Commander } \\
\text { Regulations that are } \\
\text { operational in relation } \\
\text { to IDU lecturers. }\end{array}$ & Good $(80 \%)$ \\
\hline $\begin{array}{l}\text { 2) Complete } \\
\text { internal } \\
\text { regulatory } \\
\text { bases }\end{array}$ & $\begin{array}{l}\text { There were complete } \\
\text { regulatory bases in } \\
\text { the form of Rector } \\
\text { Regulations covering } \\
\text { guidelines and SOPs } \\
\text { for career }\end{array}$ & $\begin{array}{l}\text { There were complete } \\
\text { regulatory bases in the } \\
\text { form of Rector } \\
\text { Regulations covering } \\
\text { guidelines and SOPs } \\
\text { for career }\end{array}$ & $\begin{array}{l}\text { Excellent } \\
(100 \%)\end{array}$ \\
\hline
\end{tabular}




\begin{tabular}{lll}
\hline $\begin{array}{ll}\text { development and } \\
\text { planning for IDU } \\
\text { lecturers }\end{array}$ & $\begin{array}{l}\text { development and } \\
\text { planning, supported } \\
\text { by a monitoring } \\
\end{array}$ & $\begin{array}{ll}\text { system and career } \\
\text { evaluation for IDU } \\
\text { lecturers. }\end{array}$ \\
& & $\begin{array}{l}\text { Excellent } \\
(90 \%)\end{array}$ \\
\hline Average score for regulatory bases & & \\
& & \\
\hline
\end{tabular}

Source: Research Data 2020

The data shows excellent score $(90 \%)$ from the availability of external and internal regulations which are generally sufficient and can be used as guidance in supporting career planning for IDU lecturers from TNI-soldiers. The regulations provide clear policies and mechanisms for lecturers' career. This clarity means that the process is focused on developing individual abilities to achieve the desired career (Candra in Adnyani and Dewi, 2019). Incomplete regulation issued by the TNI Commander in accommodating the provisions as stipulated in the Presidential Decree and the Minister of Defense on TNI Lecturers potentially hampers the implementation of lecturers' career in proposals for advancement in positions and ranks, especially for high-ranking officers.

\section{Program Supports}

Career support programs are various plans facilitated by IDU in supporting lecturers' career. The facilitation includes work programs related to the implementation plan for lecturers' duties and various supporting elements. As is known, as part of higher education resources, lecturers have a lecturer workload (Beban Kerja Dosen/BKD) in the form of implementing Tridharma (Three Pillars of Higher Education) which includes education, research, and community service. In order to keep the track records of lecturers' performance, apart from the Tridharma elements, it includes supporting elements. Based on various documented work programs, there are many activities that provide opportunities for lecturers to get their own points in the aspect of supporting elements.

Referring to the provisions on BKD, each semester, lecturers are expected to be responsible to perform in an equivalent to 12 semester credit units. The workload includes all components in Tridharma including education, research, and community service. From various data and observations, in general the Tridharma program has been supported by various activities including its financing.

Programs in education and teaching are the empowerment of lecturers in implementing teaching and learning process to students. In the past, IDU only administered the master program followed by a doctoral program, assigning lecturers in the field of dharma (education) experienced its own challenges. The assignment as a final assignment supervisor and final project also complements the lecturer's load. However, if we look closely, the allocation and availability of teaching loads are very limited. The study load of master and doctoral students with a minimum number of 36 credits (for master's) and 42 credits (for doctoral) is spread over 3 semesters.

According to the lecturer adequacy standard, each study program consists of at least six permanent lecturers. The available credit load allocation was not sufficient. According to documented data, IDU formulated a curriculum to 40 credits, so that an average of 3 credits of teaching educational load can be distributed each semester. In addition, IDU programmed the making of teaching materials and various training activities such as Character Program, Quality Assurance Training, Community Service Training, and various other trainings. However, from the preparation of program allocation, it did not allow all lecturers to achieve an average workload of 6 credits in teaching. 
In the field of research, IDU programs research for lecturers every year. Lecturers can submit research proposals and then is followed by a selection process. The provision of research programs for lecturers is still complemented by a reference book preparation program and a capacity building program. With this reference book writing program, lecturers have the opportunity to carry out workloads in the research field. This process is still complemented by a capacity building program that is prioritized for the allocation of support for lecturers to present their scientific works in scientific conferences both domestic and international. Based on program availability, the results show that there is still a lack of allocation plans in lecturers' research. Indeed, there are still opportunities for independent research, but it really depends on the initiative and motivation of the lecturers.

Community service programs are a part that supports the implementation of lecturers' career development. Referring to the educational curriculum, students are assigned work-study related activities on objects according to objectives. The work-study related program is designed to be a program for students; however, lecturers also participate. Lecturers are allowed to carry out community service activities through the role of being a resource person for the community in places that are the object of implementing work-study related activities.
In a series of programs in the field of community service, IDU also facilitates and assists lecturers to perform activities related to community service. Participating in external activities in the form of dissemination or becoming resource persons for lecturers, both university management and study program always facilitate this through the granting of permits and issuing an assignment warrant.

The supporting elements are not included in the implementation of Tridharma, but referring to the concept of calculating the lecturer credit score, the supporting elements are an integral part of the lecturer's career context. Supporting elements related to the lecturer's career programmed by IDU are various committees at IDU work program and budget. Lecturers are always involved in committees such as in the preparation of Rector regulations, seminar committees, training committees or workshops, and committees in cross-institutional working groups.

The results related to program supports for lecturers' career planning are summarized and presented in the following table:

Table 3. Program Supports Evaluation

\begin{tabular}{cccc}
\hline \multicolumn{2}{c}{ Description Matrix } & \multicolumn{2}{c}{ Judgement Matrix } \\
\hline $\begin{array}{c}\text { 1) Education and } \\
\text { teaching } \\
\text { program }\end{array}$ & $\begin{array}{c}\text { There was a lecturer } \\
\text { empowerment plan in } \\
\text { accordance with the } \\
\text { home base of the } \\
\text { study program in }\end{array}$ & $\begin{array}{c}\text { There is an } \\
\text { allocation of } \\
\text { education and } \\
\text { teaching and the }\end{array}$ & Good (80\%) \\
that allow lecturers \\
teaching material \\
to meet the \\
preparation program \\
educational and \\
each semester, \\
however, it was not \\
teaffing workload \\
allocation of lecturers \\
workload as a whole. \\
\end{tabular}




\begin{tabular}{|c|c|c|c|}
\hline $\begin{array}{l}\text { 2)Research } \\
\text { program }\end{array}$ & $\begin{array}{l}\text { There was a research } \\
\text { program, preparation } \\
\text { of reference books, } \\
\text { and a capacity } \\
\text { building program for } \\
\text { lecturers, however, the } \\
\text { allocation was not } \\
\text { sufficient to cover all } \\
\text { lecturers }\end{array}$ & $\begin{array}{l}\text { There is an } \\
\text { allocation of } \\
\text { research programs } \\
\text { that allow lecturers } \\
\text { to fulfill their } \\
\text { research workload }\end{array}$ & Good $(80 \%)$ \\
\hline $\begin{array}{l}\text { 3)Community } \\
\text { service program }\end{array}$ & $\begin{array}{l}\text { There was a work- } \\
\text { study related program } \\
\text { and Unhan Mengajar } \\
\text { that can be a means } \\
\text { for lecturers to } \\
\text { perform community } \\
\text { service, however, this } \\
\text { program has not } \\
\text { covered all lecturers }\end{array}$ & $\begin{array}{l}\text { There is an } \\
\text { allocation of } \\
\text { community service } \\
\text { programs that } \\
\text { allow lecturers to } \\
\text { fulfill the workload } \\
\text { of community } \\
\text { service }\end{array}$ & Good $(80 \%)$ \\
\hline $\begin{array}{l}\text { 4)Program } \\
\text { Supports }\end{array}$ & $\begin{array}{l}\text { There were various } \\
\text { committee programs } \\
\text { in the form of working } \\
\text { groups that required } \\
\text { the involvement of } \\
\text { many participants }\end{array}$ & $\begin{array}{l}\text { There is a program } \\
\text { allocation that } \\
\text { allows lecturers to } \\
\text { fulfill the workload } \\
\text { of program } \\
\text { supports }\end{array}$ & $\begin{array}{c}\text { Excellent } \\
(100 \%)\end{array}$ \\
\hline \multicolumn{3}{|c|}{ Average score for program supports } & Good $(82 \%)$ \\
\hline
\end{tabular}

\section{Source: Research Data 2020}

This data shows program supports attained good performance $(82 \%)$ from the aspects of education and teaching programs, research, community service, and supporting elements. Of the various programs provided by IDU, in general it is sufficient to support the plan to fulfill the workload of lecturers and thus also support the lecturer credit score. However, if it is detailed according to the data, the program supports for Tridharma is not optimal yet. The allocation for activities outside the supporting elements is still inadequate. This condition has the potential for lecturers to be unable to fulfill their linear workload with their credit score.

\section{Monitoring and Evaluation Plan}

Planning for career development for IDU lecturers also needs an evaluation program to check its implementation. This is highly correlated with the internal quality assurance program implemented by IDU as an institution and includes an evaluation of the lecturer workload and a comprehensive audit of the study program which ultimately includes checking the productivity of lecturers. This evaluation process is performed in relation to demands for accountability in the administration of higher education.

Institutionally, the Defense University has an internal quality assurance system at the university, faculty, and study program levels. Institutions that have functions related to quality assurance are monitoring and evaluating the performance of lecturers in executing their duties. Evaluation is carried out in order to ensure that all processes are running according to the specified standards or criteria. In the lecturer workload evaluation program, the aspect that is assessed and calculated is the fulfillment of the lecturer workload with the minimum criteria of 12 credits in each semester.

The data showed that the quality assurance department at each level has been managed by 
responsible human resources. Some of the supervisors in the quality assurance department have been certified as quality auditors. With the relatively fast dynamics of job rotation, it may imply that the qualified auditors will move departments and no longer specifically handle quality assurance.

Based on the work plan, there has been a monitoring and evaluation program for learning activities in the form of lecturer evaluation by students. The plan is still supported by activities to evaluate lecturers' workload. It is unfortunate that the evaluation plan is not detailed in checking the productivity of lecturers related to journal or scientific publication. Nevertheless, evaluation is very important to conclude the level of lecturer productivity based on meeting the criteria for lecturer productivity, including scientific papers published in local journals, seminar proceedings, nationally accredited journals, reputable international journals, and including in the form of articles in newspapers or in the form of book chapter.

The importance of detailed evaluation related to the measurement of lecturer's career achievement needs to be supported in the form of an action plan if there are standard deviations or lack of success in achieving quality objectives. That way, the work mechanism that is built will ensure that the evaluation does not stop on paper, but is followed by some actions to make improvements.

The results related to monitoring and evaluation plan are summarized and presented in the following table:

Table 4. Evaluation of Lecturer Career Monitoring and Evaluation Plans

\begin{tabular}{|c|c|c|c|}
\hline \multicolumn{2}{|c|}{ Description Matrix } & \multicolumn{2}{|c|}{ Judgement Matrix } \\
\hline Intens & Observation & Standard & Judgement \\
\hline $\begin{array}{l}\text { 1) Institution and } \\
\text { Human } \\
\text { Resources for } \\
\text { Monitoring and } \\
\text { Evaluation }\end{array}$ & $\begin{array}{l}\text { There were } \\
\text { institutions at the } \\
\text { university level, } \\
\text { faculty, and study } \\
\text { programs and partially } \\
\text { supported by certified } \\
\text { human resources }\end{array}$ & $\begin{array}{l}\text { There is a } \\
\text { monitoring and } \\
\text { evaluation agency / } \\
\text { department } \\
\text { supported by } \\
\text { competent human } \\
\text { resources working } \\
\text { in the institution }\end{array}$ & Good (80\%) \\
\hline $\begin{array}{l}\text { 2) Clarity of } \\
\text { work plan and } \\
\text { parts to be } \\
\text { evaluated }\end{array}$ & $\begin{array}{l}\text { There was a } \\
\text { monitoring and } \\
\text { evaluation plan that } \\
\text { examined the } \\
\text { implementation of the } \\
\text { lecturer workload } \\
\text { program in general }\end{array}$ & $\begin{array}{l}\text { There is a plan for } \\
\text { monitoring and } \\
\text { evaluating lecturer } \\
\text { performance, } \\
\text { career } \\
\text { achievements, and } \\
\text { a follow-up plan in } \\
\text { case of standard } \\
\text { deviation }\end{array}$ & Good $(80 \%)$ \\
\hline $\begin{array}{l}\text { Average score for } \\
\text { evaluation plans }\end{array}$ & aluation of lecturer car & r monitoring and & Good $(80 \%)$ \\
\hline
\end{tabular}

Source: Research Data 2020

The results show that monitoring and evaluation plan has good performance $(80 \%)$ obtained from data on the availability of competent monitoring institutions and supporting human resources as 
well as the monitoring and evaluation plan in the evaluation of lecturer performance in learning and lecturer workload, but not specifically detail in comprehensive lecturer productivity.

\section{Conclusion and Recommendation}

Based on the results of the evaluation discussed deriving from the integration of regulatory bases, program supports, and monitoring and evaluation plans, it is concluded that the results of the

In this regard, it is recommended that IDU is be able to make efforts to improve career development planning for TNI-soldier lecturers in order to further optimize the role of the organization as explained by Kaseger in Sesi \& Suwandana (2020) which states that organizations need to ensure the career development of people, among others, through experience and abilities suitable. A more actual recommendation is to initiate provisions for the implementation of IDU lecturer career development through the authorization of the TNI Commander as a followup or derivative of Presidential Decree No. 64/2014 on IDU Lecturers. In addition, it is also recommended to conduct further research on the implementation of the career development program, as a continuation of the research on planning in lecturer career development.

\section{References}

[1] Adnyani, Ni Luh Putu Ria \& A.A. Sagung Kartika Dewi. "Pengaruh Pengalaman Kerja, Prestasi Kerja dan Pelatihan terhadap Pengembangan Karier Karyawan.” E-Jurnal Manajemen, Vol. 8, No. 7.

[2] Ardana, I Komang, Daft, Richard L., 2010, Era Baru Manajemen, Jakarta, Penerbit: Salemba Empat.

[3] Arikunto, Suharsimi dan Cepi Safruddin Abdul Jabar. 2014. Evaluasi Program Pendidikan: Pedoman Teoretis Praktis bagi Mahasiswa dan Praktisi Pendidikan. Edisi Kedua. Jakarta: Bumi Aksara.

[4] Creswell, John W. 2017. Alih Bahasa Ahmad Fahwaid. Research Design: assessment are good (84\%). These results imply that the planning for career development for TNISoldier lecturers is sufficient in accordance with the criteria but is not optimal. Institutionally, IDU has formally planned and has the potential to encourage career development for TNI-Soldier lecturers. Referring to the criteria, the optimal assessment is between $85 \leq \mathrm{NA} \leq 100$ or is considered as excellent.

Pendekatan Kualitatif, Kuantitatif, dan Mixed. Edisi Ketiga. Yogyakarta: Pustaka Pelajar.

[5] Damanik, Burhanuddin \& Markus Bangun. 2018. "Evaluasi Kinerja Dosen Univ Sari Mutiara Indonesia dengan Menggunakan Metode Preference Ranking Organization Method for Enrichment Evaluation (Promethee)." Cess (Journal of Computer Engineering System and Science), Vol. 3 No. 2.

[6] Dessler, Gary, 2008. Manajemen Sumber Daya Manusia. Jakarta: Gramedia Pustaka Utama.

[7] Lukum, Astin. 2015. "Evaluasi Program Pembelajaran IPA SMP Menggunakan Model Countenance Stake." Jurnal Penelitian dan Evaluasi Pendidikan, Vol 9, Nomor 1.

[8] Muspawi, Mohamad. 2017. Menata Pengembangan Karier Sumber Daya Mnusia Organisasi." Jurnal Ilmiah Universitas Batanghari Jambi, Vol 17 No. 1.

[9] Sabdaningtyas, Lilik. 2018. "Model Evaluasi Kebijakan Standar Pelayanan Minimal pada Satuan Pendidikan Jenjang SD. Jurnal Penelitian dan Evaluasi Pendidikan. Vol. 22. No. 1.

[10] Sesi, Ni Putu Ade Intan \& I Gusti Made Suwandana. 2020. "Peran Motivasi Kerja Memediasi Pengaruh Pengembangan Karier terhadap Kinerja Karyawan BPR Lestari Cabang Sesetan Denpasar." EJurnal Manajemen, Vol. 9, No.6. 
[11] Silitonga, Tatar Bonar. 2008. Dasar-dasar Guru Serdadu: Praksis dan Eksis menjadi Pengajar Tentara. Yogyakarta: Aditya Media and Akademi Angkatan Udara.

[12] Silitonga, Tatar Bonar et al. 2020. Evaluation of Overseas Field Study Program at the Indonesia Defense University. International Journal of Innovation, Creativity and Change, Volume 12, Issue 10.

[13] Stufflebeam, Daniel L. and Chris L.S. Coryn, 2014. Evaluation: Theory, Models, \& Applicatons. Second Edition, San Fransisco-USA: Jossey-Bass, A Willey Brand.

[14] Terry, George R. 2016. Penerjemah J. Smith D.F.M. Prinsip-prinsip Manajemen. Cetakan keempat belas. Jakarta: PT Bumi Aksara. 